\title{
De Living Lodge natuurversterking door verblijfsrecreatie
}

Bas Amelung | Eindrapport

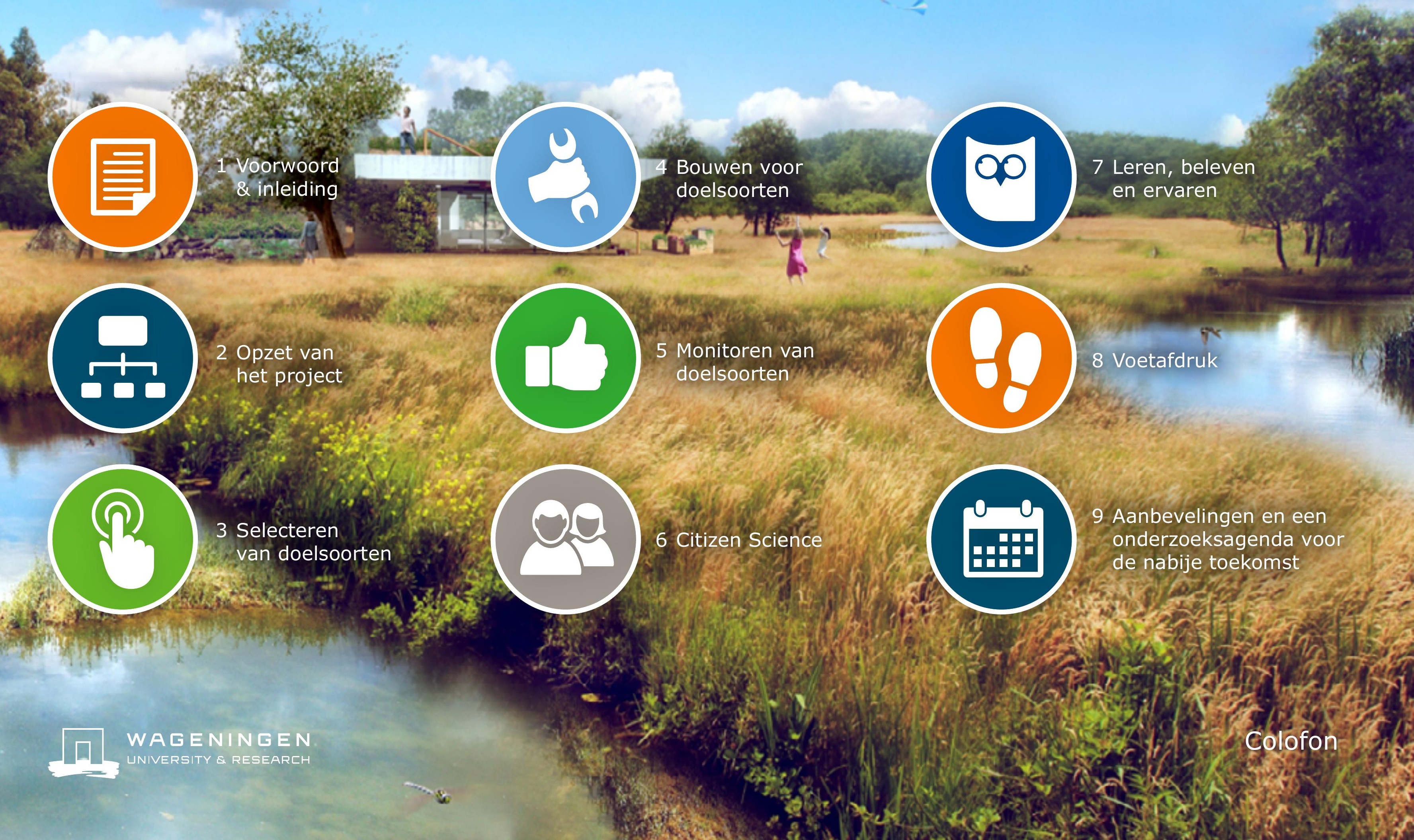


Voor u ligt het Wetenschapswinkel-rapport van de Wageningen Universiteit over de Living Lodge: het meest innovatieve en duurzame recreatieconcept van Europa en misschien wel van de hele wereld. Nature Nomads heeft met de Living Lodge een grote ambitie: door vernieuwende woon- en beleefconcepten ontstaat er een grotere binding tussen mens en natuur, en profiteert de natuur als geheel doordat er meer ruimte voor natuur en biodiversiteit ontstaat.

We geloven dat we moeten samenwerken in nieuwe coalities om deze ambitie te realiseren. Met natuurorganisaties, technologiebedrijven, bouwers, met vernieuwende designers, maar zeker ook met de wetenschap. Want een goede wetenschappelijke verankering van de vernieuwende manier waarop wij willen bouwen, ontwikkelen en recreëren is essentieel. Alleen dan weten we zeker dat flora, fauna en mensen allemaal profiteren. In dat kader hebben we samen met de Wetenschapswinkel van Wageningen University \& Research de handen ineengeslagen om deze ambitie vorm te geven.

De samenwerking van bijna 1,5 jaar is in alle opzichten uniek geweest. Het heeft geleid tot veel energie, verrassende connecties en nieuwe netwerken, heel veel plezie en zeker ook tot waardevolle nieuwe inzichten. Bovenal hebben we veel inspirerende mensen ontmoet, en ook voor ons geheel nieuwe beroepsgroepen: van experts in zweefvliegen tot experts in zelf-afbrekende bio-plastics. De breedte en diepte van ieders expertise binnen Wageningen University \& Research is echt ongekend en

indrukwekkend. Tel daar de energie van studenten bij op en dan kom je tot een bijzondere samenwerking - want dat was het!

Voor ondernemers is een vehikel als de Wetenschapswinkel cruciaal omdat de kracht van Wageningen University \& Research - zijn pluriformiteit in expertises en mensen - ook zijn zwakte is. Het was ons nooit gelukt om dit veelkoppige monster zelf te doorgronden, en we zijn nog steeds druk doende het beter te leren kennen.

Het Living Lodge project en onze startup zou niet mogelijk zijn geweest zonder mensen die, net als wij, geloven dat het anders kan en anders moet. Die risico's durven nemen. Die ergens voor durven staan. En durven gaan. Dat hebben we heel erg bijzonder gevonden. Er zijn niet heel veel mensen uit dit hout gesneden. Maar graag noemen we ze hier met naam en toenaam: Hugo Hoofwijk en Gerard Straver van de Wetenschapswinkel, zij waren de eersten die het risico met een startup aan durfden. Hugo heeft gedurende het gehele traject dag en nacht klaar gestaan om ons door het WUR-woud te geleiden, en ook nieuwe verbindingen gelegd met bijvoorbeeld de TU Eindhoven. Dank Hugo voor je tomeloze inzet

Een ander bijzonder personage in de Nature Nomads reis is Machiel Lamers. Zelden hebben we iemand ontmoet die zo'n positief doorzettingsvermogen heeft als hij. Inspirerend hoe hij met een waar pamflet ook de rest van de WUR heeft weten te mobiliseren om ook anders te durven denken en doen! Bas Amelung heeft als stille maar vastberaden kracht ook heel veel bete-
Voorwoord \& inleiding

Opzet van het project

Selecteren van doelsoorten

Bouwen voor doelsoorten

Monitoren van doelsoorten

Citizen Science

Leren, beleven en ervaren

8 Voetafdruk

9 Aanbevelingen en een onderzoeksagenda voor de nabije toekomst

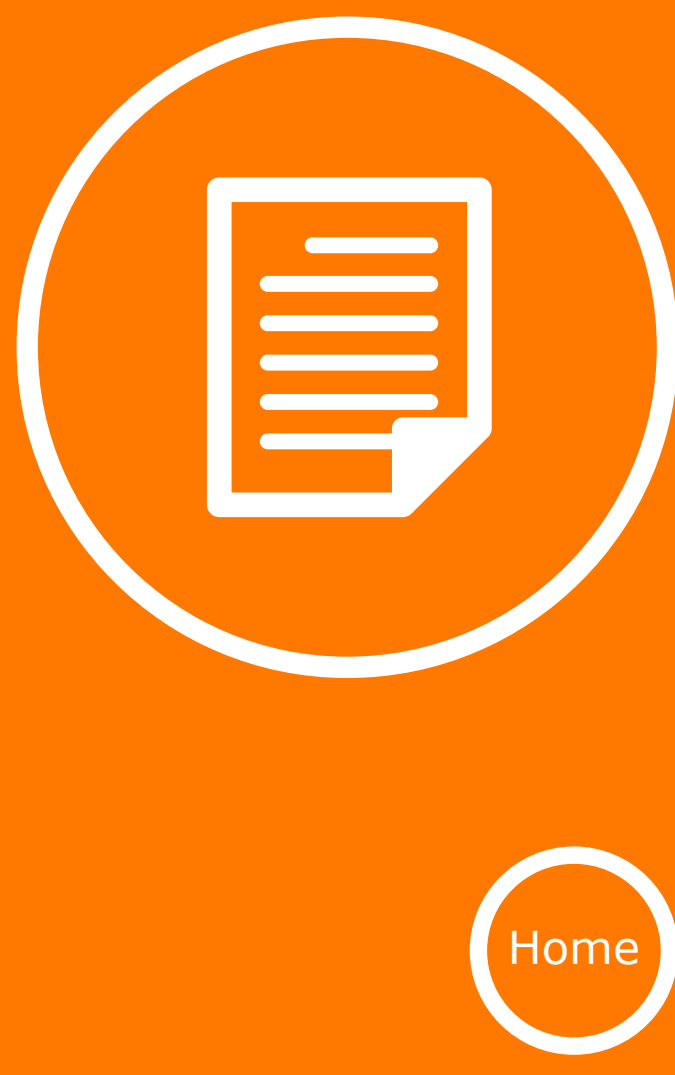




\section{Selecteren van doelsoorten}

Bouwen voor doelsoorten

Monitoren van doelsoorten

kend voor ons, in het aandragen van voortreffelijke stagiairs en een mooie verbinding gelegd met de NHTV.

Daarnaast willen we ook in het bijzonder onze andere partners bedanken die ook in dit traject hebben meegeholpen: Laetitia Linders van Staatsbosbeheer, Fred

Wouters en Jip Louwe Kooijmans van de Vogelbescherming, Albert Vliegenthart van de Vogelbescherming, Han Sluiter, Jacques van der Neut en Rob van der Made als experts en gidsen in de Biesbosch en vele andere ex-

perts uit het veld.

Tot slot natuurlijk willen we de studenten van Wageningen University \& Research hartelijk danken voor hun energie en verfrissende inzichten. In het bijzonder Julian Lührmann voor zijn ongelofelijke passie en positivisme en Asha Vergeer voor haar frisse blikken en uitstekende ecologisch pionierswerk.

Het concept is klaar om te gaan uitvoeren. Hopelijk vinden we spoedig ook bredere tractie binnen de WUR zodat we in 2050 niet meer wonen en leven in een graswoestijn maar in de meest biodiversiteitsrijke delta van Europa waar mens en natuur op een bijzondere wijze met elkaar verbonden zijn!

Op naar de toekomst!

Met wilde groet,

Herbert en Emile Smeenk 
Ruimte is schaars. We zijn met steeds meer, we worden steeds rijker en we stellen steeds strengere eisen aan comfort en kwaliteit van leven. Daardoor leggen we een steeds groter beslag op de beschikbare ruimte en staat de natuur onder druk. In de wereld als geheel en zeker ook in Nederland. We staan voor de uitdaging de wensen van de mensheid en de noden van de natuur te combineren, ook in de gebouwde omgeving. Bouwen gebeurt echter nog overwegend met de rug naar de natuur. Functionaliteit en kosten staan voorop en er is weinig oog voor de mogelijke faciliterende rol die gebouwen kunnen spelen voor de ecosystemen waarin ze zich bevinden. Deze situatie doet zich ook, en misschien wel in nog sterkere mate voor in de toeristisch-recreatieve sector. Deze sector kenmerkt zich door een grote nadruk op korte termijn winst, wat de dominantie van functionaliteit en kosten alleen maar groter maakt.

Er zit echter ook een andere kant aan dit verhaal. Zo is de toeristisch-recreatieve sector zeer afhankelijk van de natuurlijke omgeving. Landschap is één van de belangrijkste factoren die verklaren waarheen mensen op vakantie gaan of recreëren. Dat heeft onder meer te maken met de verstedelijking, die overal in de wereld plaatsvindt. Bewoners van stedelijke gebieden komen in hun dagelijks leven doorgaans weinig in contact met de natuur en moeten daarom zodoende expliciet tijd voor vrijmaken. Het is dan ook niet verwonderlijk dat de stedelijke bevolking vaker toeristische activiteiten ontplooit dan mensen uit de meer landelijke gebieden. Voor stedelingen zijn toerisme en recreatie belangrijke manie- ren om in contact te komen met de natuur

Al met al bestaat er dus flink wat spanning tussen de bouwpraktijk in de toeristisch-recreatieve sector enerzijds en de behoeften van de natuur en de verstedelijkende bevolking anderzijds. De broers Emile en Herbert Smeenk zagen daarin mogelijkheden voor vernieuwing en richtten de social enterprise Nature Nomads op.

Samen met de Vogelbescherming en Staatsbosbeheer is Nature Nomads al enige tijd bezig met het vormgeven van een nieuw concept in de toeristisch-recreatieve accommodatie: de Living Lodge. Nature Nomads wi aantonen dat mens en natuur elkaar kunnen versterken door een andere visie op hoe we bouwen, gebieden ontwikkelen en recreëren. De kennis die in deze pilot wordt opgebouwd, en de lessen die geleerd gaan worden, zullen worden gebruikt om andere mensen en organisaties te inspireren en te laten zien dat het anders kan.

De Living Lodge is gebaseerd op een drietal uitgangspunten: i) het verbinden van mens en natuur; ii) het verbeteren van biodiversiteit en iii) het minimaliseren van de eigen negatieve voetafdruk m.b.t. het gebruik van energie, water en andere natuurlijke hulpbronnen. Implementatie van deze uitgangspunten is niet eenvoudig, maar inmiddels tekenen de contouren van de Living Lodge zich duidelijk af. De Lodge zelf biedt aan de binnenkant een habitat die comfortabel is voor de gasten, en aan de buitenkant één of meerdere habitats die comfortabel zijn voor de plant- en diersoorten die in het
Voorwoord \& inleiding

Opzet van het project

Selecteren van doelsoorten

Bouwen voor doelsoorten

Monitoren van doelsoorten

6 Citizen Science

7 Leren, beleven en ervaren

8 Voetafdruk

9 Aanbevelingen en een onderzoeksagenda voor de nabije toekomst

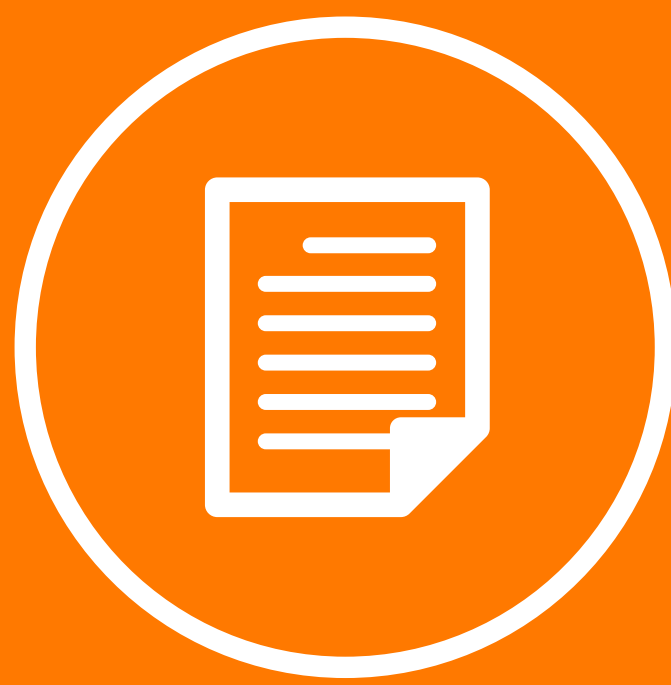


gebied een steuntje in de rug kunnen gebruiken. De Living Lodge wordt geplaatst in afgelegen, spannende natuurgebieden, waar voor de gasten veel te ontdekken valt en waar ruimte is voor natuurversterking. Zo zal de eerste Living Lodge verrijzen in de Biesbosch. De bedoeling is dat de buitenkant van de Lodge op termijn met de omgeving zal vergroeien en permanent onderdeel van het ecosysteem gaat uitmaken. De binnenkant wordt zo ontworpen dat deze uit de buitenschil kan worden gehaald en elders weer in een andere Living Lodge kan worden ingebouwd.

Toen de ideeën voor de Lodge op hoofdlijnen waren uitgekristalliseerd, brak voor het Living Lodge programma een nieuwe fase aan: die van verdere concretisering en het toewerken naar een prototype. In die fase moesten nog tal van problemen worden opgelost en vragen worden beantwoord, zoals: hoe selecteer je de doelsoorten die je wilt ondersteunen; hoe kun je die ondersteuning het best bieden; hoe kun je de Living Lodge zo zelfvoorzienend mogelijk maken; hoe kun je de ervaring van de gasten zo intens en inspirerend mogelijk maken? Op zoek naar de benodigde kennis om die vragen te beantwoorden ging het Living Lodge team te rade bij de Wetenschapswinkel van Wageningen University \& Research. Het Wetenschapswinkel project Living Lodge ging halverwege 2015 van start, met als kader een plan van aanpak, waarin onder meer de belangrijkste te beantwoorden vragen staan vermeld. Binnen dit kader is een bonte verzameling van studenten met die vragen aan de slag gegaan, binnen een consultancy-opdracht, als groepswerk, of als stage- of thesisonderwerp. Dit rapport doet verslag van die verschillende deelprojecten en hun resultaten. Het is bedoeld als een overzicht op hoofdlijnen van wat er uit de afgeronde onderzoeken is gekomen en welke vragen nog open zijn of tijdens het onderzoek zijn opgekomen.

Het rapport is als volgt opgebouwd. Hoofdstuk 2 geeft een overzicht van het Wetenschapswinkelproject, inclusief doelen en de bijdrage van de verschillende deelprojecten. De hoofdstukken $3 \mathrm{t} / \mathrm{m} 8$ gaan in op een aantal hoofdthema's in het Wetenschapswinkelproject: het selecteren van doelsoorten (H3); het in kaart brengen van de habitateisen van de geselecteerde soorten en de mogelijkheden om op die eisen in te spelen bij ontwerp en bouw ( $\mathrm{H} 4)$; het monitoren van de doelsoorten ( $\mathrm{H} 5)_{\text {; }}$ het betrekken van gasten bij monitoring en onderzoek (H6); het stimuleren en intensiveren van de (leer) ervaring van gasten $(\mathrm{H} 7)$; en het minimaliseren van de ecologische voetafdruk (H8). Veel deelonderzoeken hebben de Biesbosch als casus gebruikt, omdat daar de eerste Living Lodge geplaatst zal worden. Die casuïstiek is in de afzonderlijke hoofdstukken verwerkt. Hoofdstuk 9 grijpt terug naar de projectdoelen uit hoofdstuk 2, evalueert welke doelen zijn gerealiseerd en geeft een aanzet voor een onderzoeksagenda voor de nabije toekomst.
Voorwoord \& inleiding

Opzet van het project

Selecteren van doelsoorten

Bouwen voor doelsoorten

Monitoren van doelsoorten

6 Citizen Science

Leren, beleven en ervaren

8 Voetafdruk

9 Aanbevelingen en een onderzoeksagenda voor de nabije toekomst

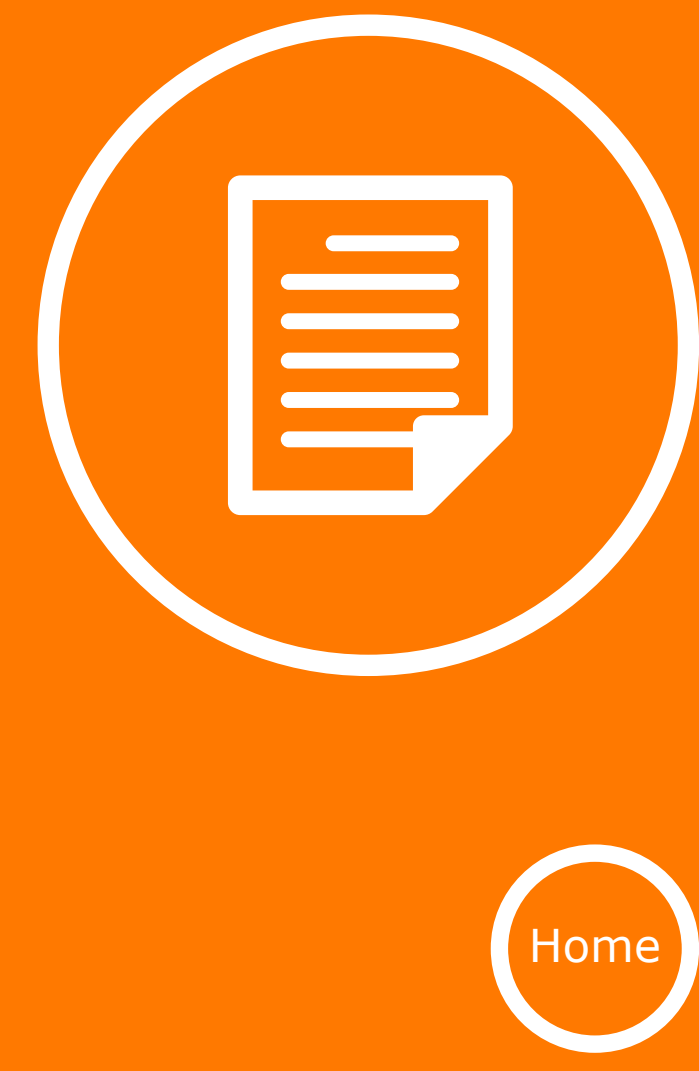


In 2015 dienden de Nature Nomads samen met de Vogelbescherming een aanvraag in bij de Wetenschapswinkel om onderzoek te laten uitvoeren door studenten. De Wetenschapswinkel ontvangt zulke verzoeken regelmatig, maar kan er slechts enkele per jaar honoreren. Besloten werd het Living Lodge project te financieren, vanwege de kwaliteit van zowel de aanvraag en de aanvrager. Het idee voor de Living Lodge is innovatief en heeft sterke raakvlakken met een aantal belangrijke onderzoeksthema's van Wageningen University \& Research: ecologie, kwaliteit van leven en verduurzaming. Daarnaast werd de aanvraag voor ondersteuning door de Wetenschapswinkel ingediend door een ambitieuze social enterprise start-up: Nature Nomads. Nature Nomads heeft weliswaar op langere termijn een winstdoelstelling, maar wordt vooral gedreven door de wens om een maatschappelijke bijdrage te leveren.

Het project is ondergebracht bij de leerstoelgroep Environmental Systems Analysis (ESA). Voor de begeleiding en bijsturing van het Living Lodge project is een Begeleidingscommissie ingesteld, die projectleider en onderzoekers van advies heeft voorzien op een aantal vaste momenten: bij de projectstart, tijdens een tussentijdse bespreking en bij de bespreking van het conceptrapport. De Begeleidingscommissie dacht mee over de afsluiting van het project. Ook is er gedurende het project regelmatig contact geweest tussen individuele leden van de commissie en de onderzoekers.
In nauw overleg met de klantorganisaties, diverse medewerkers van Wageningen University \& Research en de Begeleidingscommissie is voor dit Wetenschapswinkelproject de volgende hoofdvraag geformuleerd:

Kan de biodiversiteit in een gebied in principe worden ondersteund door middel van zelfvoorzienende verblijfsrecreatie volgens het Living Lodge concept? Zo ja, hoe?

Deze hoofdvraag omvat een drietal belangrijke aspecten: i) wat kan de natuur aan een lodge hebben (ecologie-aspect)? ii) wat kan de gast aan een lodge hebben (mens-aspect)? en iii) hoe kun je zo'n lodge eigenlijk bouwen (techniek-aspect)? Deze drie hoofdaspecten vormen de basis voor drie onderzoeksclusters: i) cluster ecologie, ii) cluster mens en iii) cluster techniek. Voor elk van deze hoofdclusters zijn meer gedetailleerde kernvragen geformuleerd:
Selecteren van doelsoorten

Bouwen voor doelsoorten

Monitoren van doelsoorten

Citizen Science

7 Leren, beleven en ervaren

8 Voetafdruk

9 Aanbevelingen en een onderzoeksagenda voor de nabije toekomst

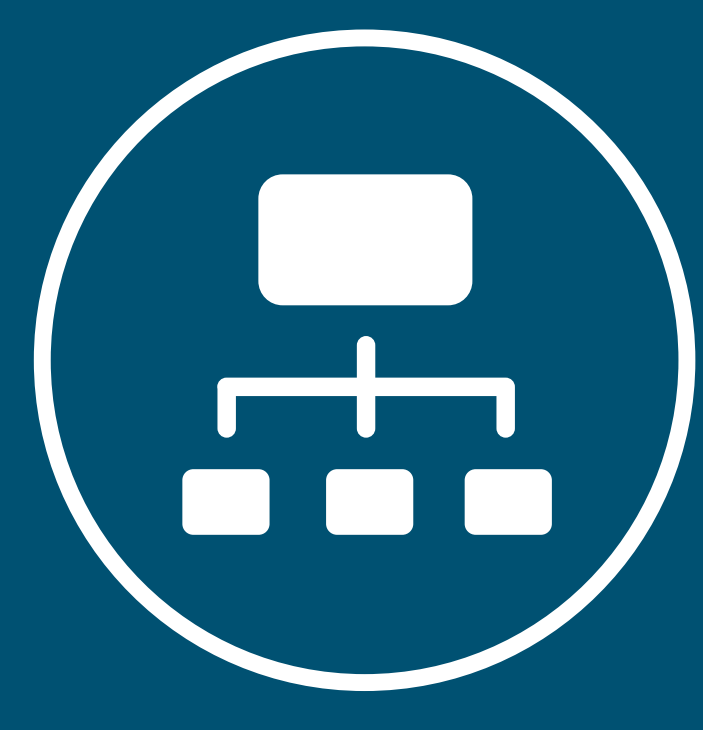




\section{Cluster ecologie}

1.1. Hoe kan de ecologische waarde van een gebied in kaart worden gebracht via een nulmeting?

1.2. Via welke methode kan een shortlist van doelsoorten voor de Living Lodge worden samengesteld? Wat zijn de biotoop-vereisten voor deze doelsoorten? Wat zijn de soorten die mee kunnen liften met de doelsoorten?

1.3. Met welke aanpak kan, gegeven de locatie, een onderbouwde keuze worden gemaakt voor één of meerdere doelsoorten?

1.4. Welke ondersteuningsmaatregelen (voedsel, veiligheid, voortplanting) zijn mogelijk gelet op de biotoopvereisten van de doelsoorten? Hoe kan dit gerealiseerd worden in/op/rondom/tegen de lodge?

\section{Cluster techniek}

2.1. Gegeven de biotoop-vereisten van de doelsoorten: welke bouwtechnieken en constructie-elementen kunnen worden gebruikt voor de buitenschil van de logde zodat maximaal aan die biotoop-vereisten tegemoet wordt gekomen?

2.2. Welke vernieuwende (bio-based/biomimicry) duurzame bouwtechnieken en -materialen kunnen worden gebruikt voor het verblijfsgebied (de kern)? Deze technieken en materialen moeten de negatieve voetafdruk minimaliseren, en kostentechnisch interessant zijn. Tevens is van belang dat het verblijfsgebied een goed binnenklimaat heeft, brandveilig is en dat de natuur niet (ongecontro- leerd) in het verblijfsgebied naar binnen komt.

2.3. Hoe zorg je voor een autarkisch energie- en watersysteem? Doel is om hierin verder te gaan dan bestaande producten en concepten door optimaal gebruik te maken van de omgeving.

\section{Cluster mens}

3.1. Welke ecosysteemdiensten kan het Living Lodge concept leveren? Belangrijk daarbij zijn de materiële, maar zeker ook de niet-materiële ecosysteemdiensten.

3.2. Welke high-tech innovaties kunnen ingezet worden om de natuurbeleving van de gasten van de Living Lodge te vergroten?

3.3. Welke low-tech innovaties kunnen ingezet worden om de natuurbeleving en -educatie van de gasten van de Living Lodge te vergroten? Dit zowel in de "hardware", zoals belevingselementen in het gebouw zelf (in de constructie of levende schil, van binnen de lodge en van buiten) als in de "software" zoals activiteiten.

3.4. Op welke manier kunnen de gasten van de Living Lodge een actieve bijdrage leveren aan de kwaliteit van het ecosysteem?

3.5. Op welke manier kunnen de gasten van de Living Lodge een bijdrage leveren aan de monitoring van biodiversiteit (zie ook cluster ecologie)?

Het Wetenschapswinkelproject is modulair opgebouwd. Dat houdt in dat het onderzoek in diverse deelonderzoe-
Selecteren van doelsoorten

4 Bouwen voor doelsoorten

5 Monitoren van doelsoorten

6 Citizen Science

Leren, beleven en ervaren

8 Voetafdruk

9 Aanbevelingen en een

onderzoeksagenda voor de nabije toekomst

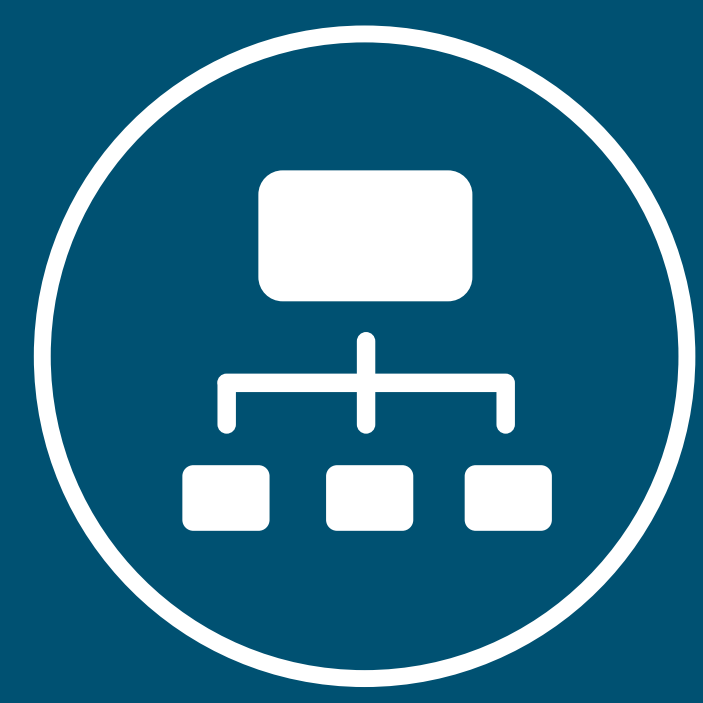


ken is opgesplitst die onafhankelijk van elkaar zijn uitgevoerd. Vanaf het begin was het voor alle partijen duidelijk dat mogelijk niet alle deelvragen beantwoord zouden worden, of zelfs aan bod zouden komen. Het kon immers zijn dat voor enkele onderdelen geen studenten zouden worden gevonden, of dat het geleverde werk van matige kwaliteit zou zijn.

Expertise op het vlak van bouwkunde was in Wageningen niet voorhanden. Voor een aantal vragen uit de cluster techniek is daarom de hulp ingeschakeld van de Bouwkundewinkel van de Technische Universiteit Eindhoven.

Aan het project hebben uiteindelijk studenten uit diverse studierichtingen bijgedragen, met name uit de bachelor-opleidingen BSc Tourism (Wageningen), BSc Environmental Sciences (Wageningen) en BSc Architecture, Urbanism and Building Sciences (Eindhoven). Bij drie deelprojecten ging het om groepswerk, namelijk binnen de vakken Academic Consultancy Training (ACT), Environmental Project Studies (ETE-25812) en de opdracht aan de bouwkundewinkel van de Universiteit Eindhoven. De overige deelprojecten werden uitgevoerd als individueel onderzoek, maar wel op verschillende manieren vorm gegeven. Drie studenten hebben een BSc thesis geschreven over een Living Lodge onderwerp. Daarnaast hebben zes groepen studenten een essay geschreven over de Living Lodge, binnen het BSc-vak Sustainable Technology Development (ENP-38803). Tenslotte hebben twee studenten hun stage aan Living Lodge gewijd. Zie de colofon voor een volledige opsomming van de deelnemende studenten
Voorwoord \& inleiding

Opzet van het project

Selecteren van doelsoorten

4 Bouwen voor doelsoorten

Monitoren van doelsoorten

6 Citizen Science

Leren, beleven en ervaren

8 Voetafdruk

9 Aanbevelingen en een

onderzoeksagenda voor de nabije toekomst

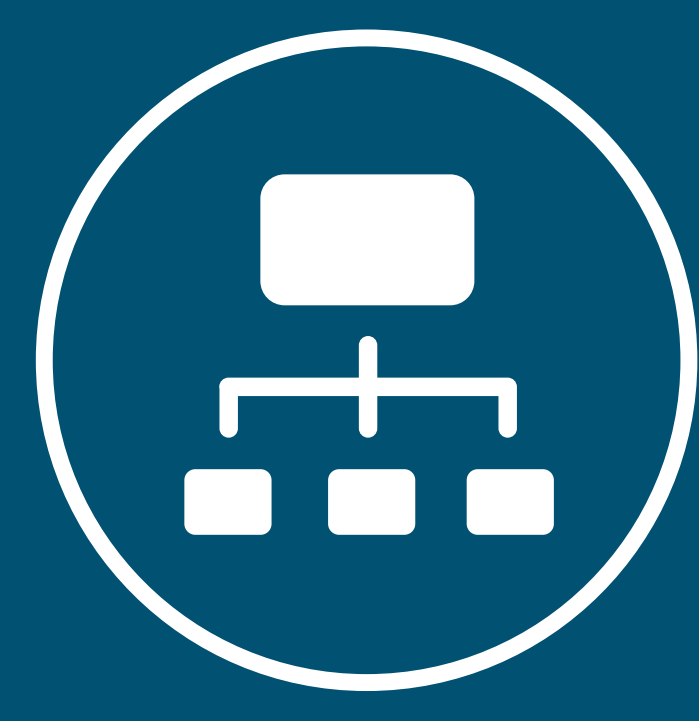




\section{Belangrijkste inzichten}

- Een methode is ontwikkeld om met behulp van Natura 2000 en de Rode Lijst snel een overzicht te krijgen van mogelijke doelsoorten voor de Living Lodge.

- Deze methode is uitgewerkt voor de Brabantse Biesbosch, maar kan ook worden gebruikt voor toekomstige locaties van de Living Lodge.

\section{Samenvatting}

Eén van de hoofddoelen van het Living Lodge concept is het ondersteunen van het ecosysteem waarin de Lodge zich bevindt, door het bieden van een aantrekkelijke habitat voor een aantal doelsoorten. Maar welke soorten en hoe selecteer je die? Dat was een centrale vraag voor een groep studenten die in het kader van het vak Academic Consultancy Training (ACT) een studie deden naar de ecologische mogelijkheden van de Living Lodge.

De groep stelt voor om bij de selectie van doelsoorten een aantal stappen te doorlopen: twee stappen als er alleen planten worden ondersteund, vier stappen als er planten en dieren worden ondersteund. Dat onderscheid drukt uit dat dieren vegetatie nodig hebben en daarnaast vaak ook structurele elementen in het landschap.

In stap één worden de habitattypen die in het doelgebied voorkomen in kaart gebracht, en ook de daarbij behoren-

\section{Toekomst}

- De ontwikkelde methode is vooral gebaseerd op ecologische overwegingen. Nader onderzoek naar de voorkeuren van de gasten van de Living Lodge kan helpen de groslijst verder te verkorten.

de plantensoorten. Hiervoor wordt de Natura-2000 classificatie gebruikt, omdat deze zeer gangbaar is en de databeschikbaarheid ervan goed is. Vervolgens wordt op basis van waarnemingen nagegaan welke van deze soorten zich daadwerkelijk in het gebied bevinden.

Stap twee betreft het kiezen van doelsoorten uit de lijst van aanwezige soorten. De ACT-groep stelt voor om die keuze te baseren op drie criteria: beschermingsstatus, ecologische waarde en aaibaarheid (aantrekkelijkheid voor mensen). De procedure daarvoor kan in vervolgonderzoek verder worden uitgewerkt.

Stap drie richt zich op het in kaart brengen van structurele elementen in het landschap, zoals waterpartijen en struikgewas, omdat deze elementen voorwaarden zijn voor sommige diersoorten om zich ergens te vestigen.
4 Bouwen voor doelsoorten

5 Monitoren van doelsoorten

6 Citizen Science

7 Leren, beleven en ervaren

8 Voetafdruk

9 Aanbevelingen en een onderzoeksagenda voor de nabije toekomst

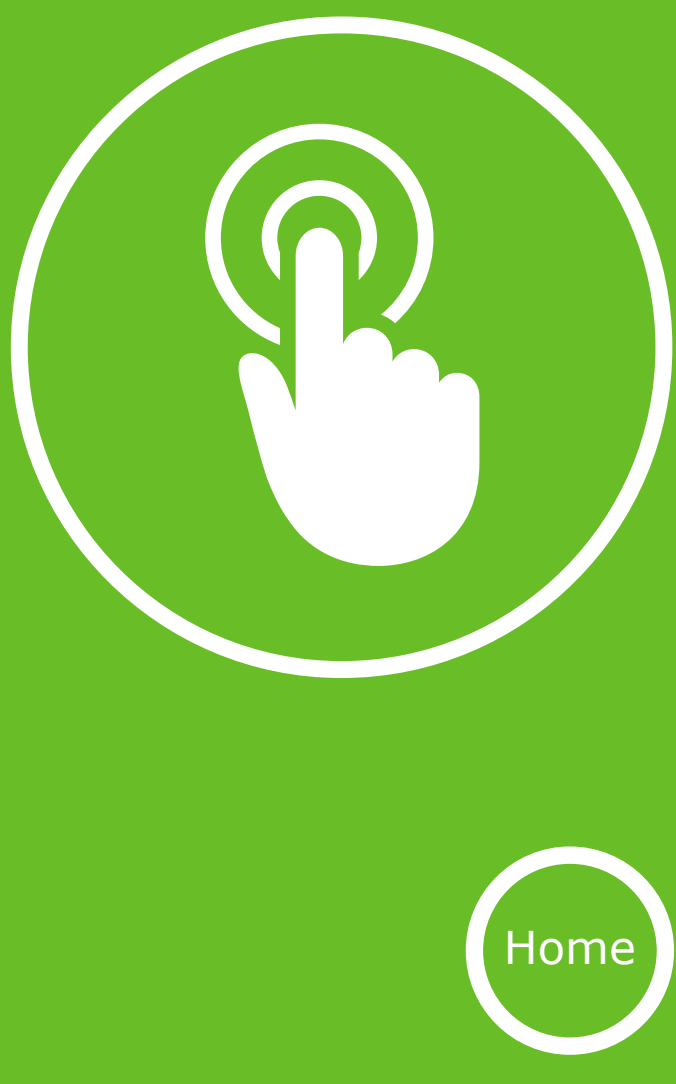


Stap vier heeft allereerst tot doel het lijstje van mogelijke dierlijke doelsoorten te beperken door te filteren op basis van aanwezige habitats, specifieke plantensoorten en structurele elementen in het landschap. De ACT-groep stelt voor een definitieve keuze voor doelsoorten te maken op basis van de drie criteria uit stap twee: beschermingsstatus, ecologische waarde en aaibaarheid. Ook deze keuzemethode kan in vervolgonderzoek verder worden uitgewerkt.

De ontwikkelde methode is toegepast op de Biesbosch. In dit gebied komen volgens Natura 2000 zes verschillende typen habitat voor: i) beken en rivieren met waterplanten; ii) slikkige rivieroevers; iii) ruigten en zomen; iv) vochtige alluviale bossen; v) stroomdalgraslanden; en vi) glanshaver- en vossenstaarthooilanden. In het Brabantse deel van de Biesbosch komen alleen habitattype i t/m iv voor, en daar richt de verdere analyse zich op. In deze habitats komen veel plantensoorten voor, maar alleen díe soorten zijn geselecteerd die op de Rode Lijst tenminste als 'zeldzaam' zijn aangemerkt en die typisch zijn voor zoetwater-getijdegebieden. Het ACT-rapport komt uit op 19 plantensoorten als mogelijke doelsoorten, waarvan er na overleg met een expert 15 overblijven, en 5 soorten mos. Het is aan de initiatiefnemers van de Living Lodge om uit deze groslijst een keuze te maken.

Voor wat betreft diersoorten die mogelijk doelsoorten zouden kunnen zijn, onderscheidt het ACT-rapport 29 vogelsoorten, 8 libellensoorten, 25 vlindersoorten en 6 zoogdiersoorten. Met name voor de libellensoorten en de vlindersoorten biedt het rapport een overzicht van de voornaamste plantensoorten waarvan deze diersoorten afhankelijk zijn. Bij de vogel- en zoogdiersoorten wijst het rapport vooral op belangrijke landschapselementen en op de risico's van verstoring door de mens.

\section{Bron}

- Van der Laan, A., Ramachandra, G., Van den Top, G. Suijker, K., Sreenivasan, N., en Saha, S. (2016). The Living Lodge: Accommodating life. An assessment of integration and monitoring of biodiversity. Eindrapport van Academic Consultancy Training (ACT) groep 1666. Wageningen University \& Research, Wageningen, Nederland.

Dit rapport is te downloaden vanaf de website van de wetenschapswinkel.

\section{Toekomst}

Samenvatting

Bron

Bouwen voor doelsoorten

5 Monitoren van doelsoorten

6 Citizen Science

Leren, beleven en ervaren

8 Voetafdruk

9 Aanbevelingen en een onderzoeksagenda voor de nabije toekomst

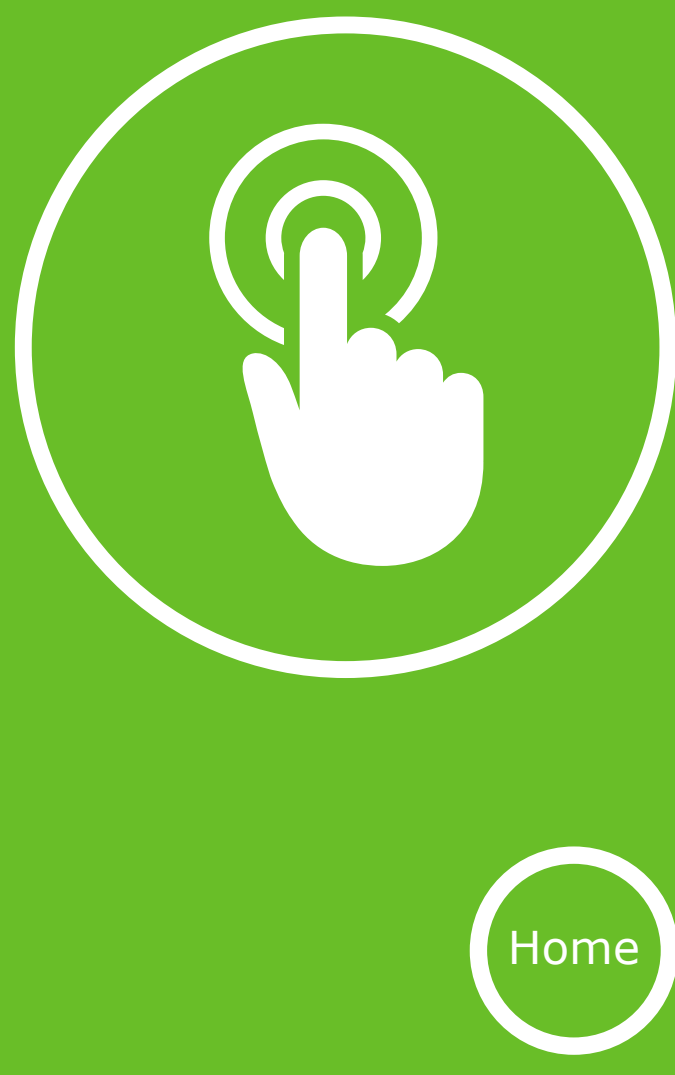




\section{Belangrijkste inzichten}

- Het onderzoek heeft een overzicht en classificatie opgeleverd van de beschikbare typen groenstructuren die kunnen zorgen voor een prettiger leefomgeving voor de doelsoorten. Deze groenstructuren kunnen zowel biotisch als abiotisch zijn.

- Het eerste bouwkundig onderzoek biedt een verkenning van mogelijke vormen van de Living Lodge en de toepassing daarin van groenstructuren.

- Het tweede bouwkundig onderzoek stelt voor de Living Lodge te voorzien van een levende gevel, een soort voorzetgevel die naar wens kan worden ingevuld om te voldoen aan de eisen van specifieke doelsoorten.

\section{Samenvatting}

Het ACT-rapport bevat een inventarisatie van de mogelijkheden om het de doelsoorten naar de zin te maken via zogeheten groenstructuren. Het onderscheidt daarbij biotische en abiotische mogelijkheden. Tot de biotische mogelijkheden behoren verticale componenten, zoals verticale tuinen en levende muren, maar ook groene daken en tuintjes voor wilde bloemen. Tot de abiotische mogelijkheden behoren zandhopen, poeltjes, rotstuinen, houtwallen, hibernaria (vorstvrije schuilplaatsen), insectenhotels en vleermuis- en nestkasten. Vervolgonderzoek kan verder verhelderen hoe de diverse groenstructuren in kunnen spelen op de eisen van de verschillende doelsoor-

\section{Toekomst}

- De behoeftes van geselecteerde doelsoorten kunnen verder in kaart worden gebracht en vertaald in bouweisen, dan wel eisen aan de invulling van de levende gevel.

ten en hoe de groenstructuren in de Living Lodge geïntegreerd kunnen worden.

Een eerste aanzet tot het koppelen van specifieke soorten aan specifieke groenstructuren is gedaan door Asha Vergeer tijdens haar stage. De bouwkundige kant is nader onderzocht via twee Bouwkundewinkelprojecten aan de Universiteit Eindhoven. In het eerste project (Van de Werdt en Bilici, 2017) hebben twee studenten in totaal zes mogelijke ontwerpen gemaakt voor de Living Lodge. Deze ontwerpen verschillen flink van elkaar in termen van mogelijkheden om ruimte te bieden aan planten en dieren.

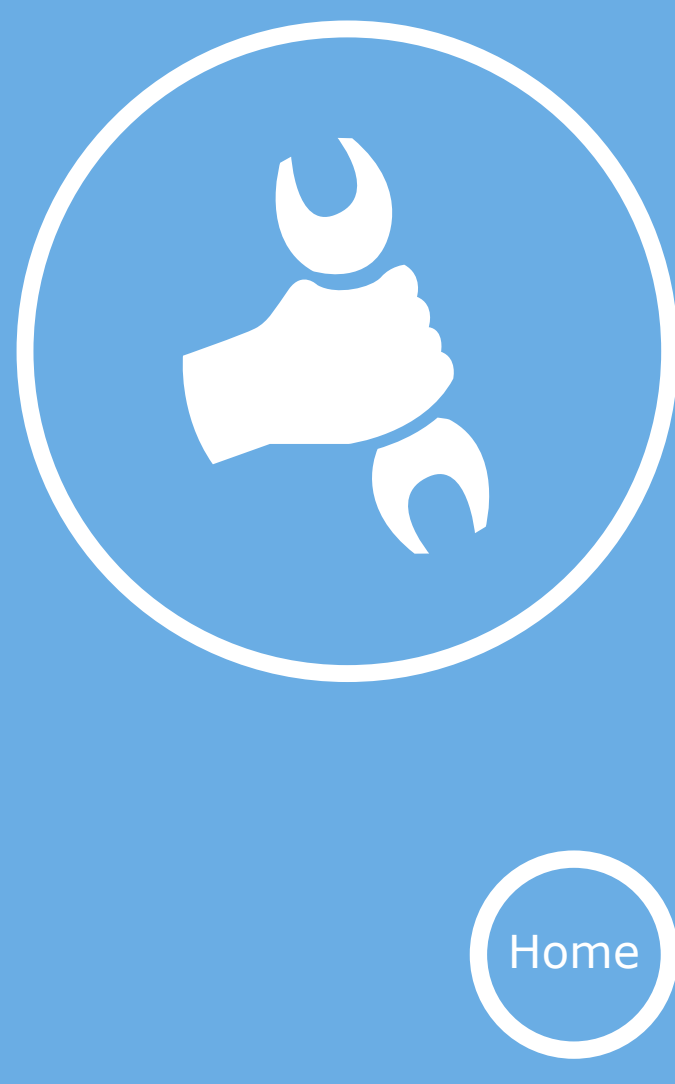


Zo hebben sommige ontwerpen grote oppervlaktes aan dak en gevel, terwijl andere ontwerpen juist veel kleinere ruimtes bieden.

Het tweede rapport, van Nijkamp en collega's (2017), benadert de koppeling tussen doelsoorten en ontwerp vanuit een nieuw en interessant perspectief. De auteurs doen namelijk een voorstel voor een levende gevel met een vaste indeling in vakken, maar waarvan de invulling van die vakken geheel vrij is. Het rapport noemt een aantal mogelijkheden, waaronder algenpanelen die biomassa leveren en kunnen zorgen voor zonwering, insectenhotels, groene wanden of kruidenwanden en broed- of slaapplaatsen voor vogels en vleermuizen. De levende gevel staat qua constructie geheel los van de leef-modules van de lodge. Zodoende is de Living Lodge dus niet doelsoort-specifiek, maar kunnen door aanpassing van de levende gevel in beginsel steeds andere doelsoorten worden bediend.

Het rapport van Nijkamp en collega's doet verder suggesties voor het gebruik van innovatieve materialen. De levende gevel kan worden gemaakt van biocomposiet, bestaande uit vezels en hars die beide bio-based zijn. Voor de ingang zou BioMASON gebruikt kunnen worden, een milieuvriendelijk alternatief voor bakstenen. BioMASON kan op de bouwplaats worden gekweekt uit micro-organismen en zonder verhitting worden verhard, waardoor het energiegebruik laag blijft.

\section{Bronnen}

- Nijkamp, N., Kleine Schaars, D., Hein, A., Steeghs, T., en Limpens, P. (2017). Eindverslag bouwkundewinkel project Living Lodge. University of Technology Eindho ven, Eindhoven.

Dit rapport is op te vragen bij de bouwkundewinkel.

- Van der Laan, A., Ramachandra, G., Van den Top, G. Suijker, K., Sreenivasan, N., en Saha, S. (2016). The Living Lodge: Accommodating life. An assessment of integration and monitoring of biodiversity. Eindrapport van Academic Consultancy Training (ACT) groep 1666. Wageningen University \& Research, Wageningen. Dit rapport is te downloaden vanaf de website van de wetenschapswinkel.

- Van de Werdt, N. en Bilici, T. (2017). Bouwkundewinkel rapport Living Lodge. University of Technology Eindhoven, Eindhoven.

Dit rapport is op te vragen bij de bouwkundewinkel.

- Vergeer, A. (2017). Eindrapport stage Living Lodge.

Wageningen University \& Research, Wageningen.

Dit rapport is op te vragen bij de leerstoelgroep Plantenecologie en Natuurbeheer (PEN).
1. Voorwoord \& inleiding

Opzet van het project

Selecteren van doelsoorten

Bouwen voor doelsoorten Belangrijkste inzichten

Toekomst

Samenvatting

Bron

5 Monitoren van doelsoorten

6 Citizen Science

7 Leren, beleven en ervaren

8 Voetafdruk

9 Aanbevelingen en een onderzoeksagenda voor de nabije toekomst

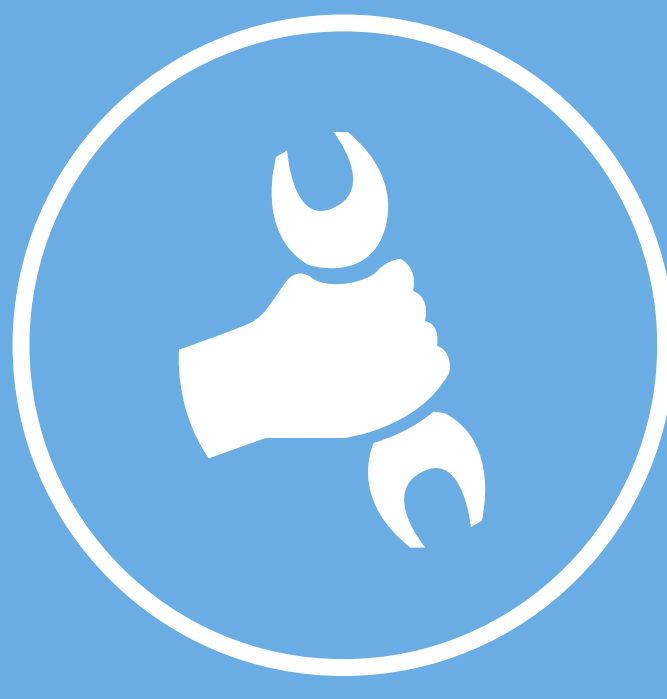




\section{Belangrijkste inzichten}

- Het onderzoek heeft een stappenplan opgeleverd om doelsoorten te monitoren.

\section{Samenvatting}

De ACT-groep biedt een vrij uitgebreide beschrijving van een monitoringssysteem voor de plant- en diersoorten die in en rondom de Living Lodge leven. De groep neemt daarbij het door Franklin et al. (2011) ontwikkelde raamwerk als uitgangspunt. Dit raamwerk bestaat uit zes stappen: 1) formulering van het algemene doel van de monitoring; 2) prioritering van taxonomische groepen; 3) formulering van de specifieke monitoringdoelen; 4) ontwikkeling van een monitoringplan; 5) uitvoering van het plan; 6) het trekken van conclusies.

Volgens de ACT-groep is het hoofddoel van monitoring in het geval van de Living Lodge het nagaan of de Living Lodge de biodiversiteit kan verbeteren. De groep stelt voor dit te doen via het monitoren van het aantal soorten en het aantal individuen per soort. Monitoringplannen zijn uitgewerkt voor de volgende taxonomische groepen:

vogels, zoogdieren, libellen, vlinders en geleedpotigen. In die plannen spelen niet alleen experts een rol, maar ook de exploitanten van de Living Lodge en de Lodge-bezoekers, via Citizen Science.

\section{Toekomst}

- Zodra de precieze doelsoorten zijn geselecteerd, kan het monitoringsplan verder worden ingevuld, waar mogelijk gebruikmakend van Citizen Science (zie volgende hoofdstuk)

\section{Bron}

- Van der Laan, A., Ramachandra, G., Van den Top, G., Suijker, K., Sreenivasan, N., en Saha, S. (2016). The Living Lodge: Accommodating life. An assessment of integration and monitoring of biodiversity. Eindrapport van Academic Consultancy Training (ACT) groep 1666 Wageningen University \& Research, Wageningen.

Dit rapport is te downloaden vanaf de website van de wetenschapswinkel.

\begin{tabular}{ll}
\hline 1 & Voorwoord \& inleiding \\
\hline 2 & Opzet van het project \\
\hline 3 & Selecteren van doelsoorten \\
\hline 4 & Bouwen voor doelsoorten \\
\hline 5 & Monitoren van doelsoorten \\
\hline & Belangrijkste inzichten \\
\hline & Toekomst \\
\hline & Samenvatting \\
\hline & Bron \\
\hline 6 & Citizen Science \\
\hline 7 & Leren, beleven en ervaren \\
\hline 8 & Voetafdruk \\
\hline 9 & $\begin{array}{l}\text { Aanbevelingen en een } \\
\text { onderzoeksagenda voor de } \\
\text { nabije toekomst }\end{array}$ \\
\hline
\end{tabular}

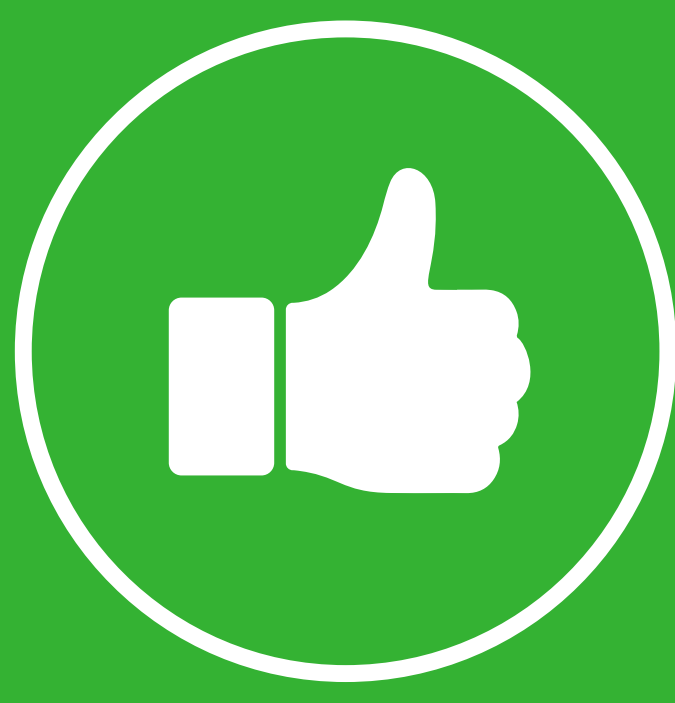




\section{Belangrijkste inzichten}

- Citizen Science kan een bijdrage leveren aan het monitoren van de ecologische ontwikkelingen rond de Living Lodge.

- Tegelijkertijd kan Citizen Science ook bijdragen aan de natuurbeleving van de gasten van de Living Lodge.

- Een ruime meerderheid van de potentiële gasten heeft belangstelling voor Citizen Science.

- Belangrijke aanknopingspunten zijn: creëer mogelijkheden voor experimenten, laat zien hoe de gast bijdraagt aan natuurbescherming, houd het leuk en eenvoudig, en koppel de resultaten naar de gast terug.

\section{Samenvatting}

Citizen Science betreft de betrokkenheid van leken (burgers) bij wetenschappelijk onderzoek. Citizen Science komt al eeuwen voor, maar heeft de afgelopen jaren mede onder invloed van technologische ontwikkelingen een hoge vlucht genomen.

De inzet van burgers stelt de wetenschap in staat om vee omvangrijkere en langere datasets op te bouwen dan anders mogelijk was geweest. De positie van de deelnemende burger kan op verschillende manieren worden ingevuld. De burger kan aan projecten bijdragen, erin samenwerken en ze co-creëren. Het spectrum loopt dus van 'crowdsourcing', waarbij de burger fungeert als sensor,

\section{Toekomst}

- Een belangrijke vervolgvraag is of er een Citizen Science project is waarbij de Living Lodge kan aansluiten of een thema waaromheen een nieuw project geformuleerd kan worden.

tot aan 'extreme citizen science', waarbij de burger ook bijdraagt aan het bedenken en ontwerpen van een project. Dat laatste komt nog weinig voor. In de meeste gevallen levert de burger alleen een bijdrage door het aanleveren van data, zonder verder betrokken te zijn bij de verdere analyse daarvan. Vaak zijn burgers wel voor langere tijd bij een project betrokken.

Langdurige betrokkenheid van burgers is lastig in een toeristische context zoals bij de Living Lodge. Een ander punt van aandacht is het motief van mensen om betrokken te zijn bij Citizen Science projecten. In een toeristisch-recreatieve context is het belangrijk dat Citizen

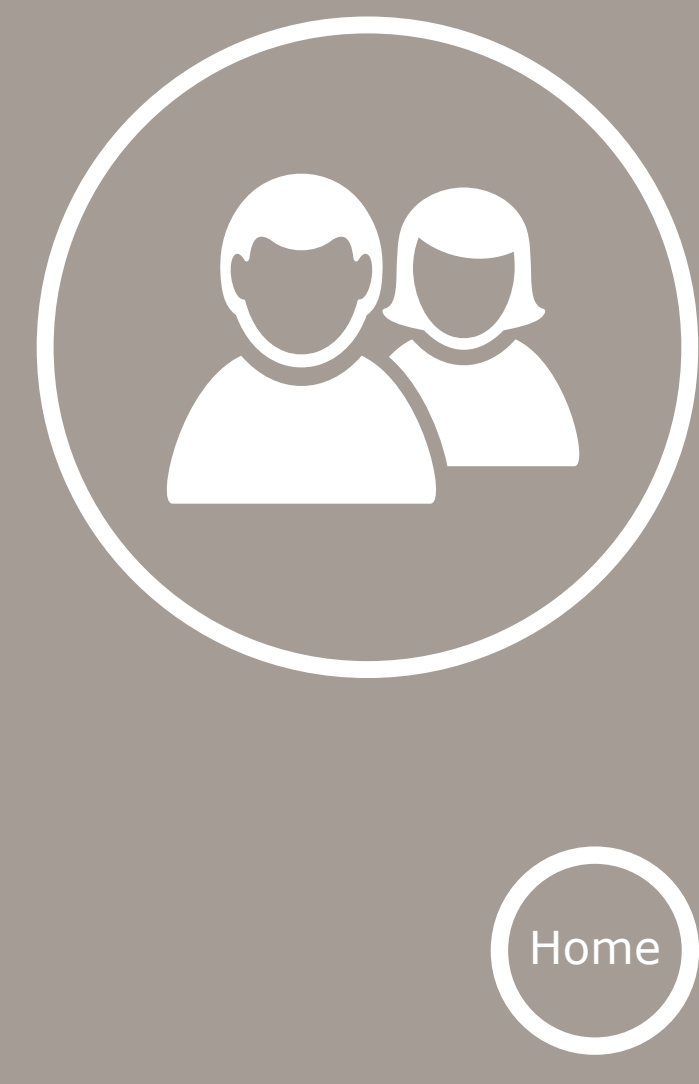


Science bijdraagt aan beleving en niet als plicht wordt gezien. In haar thesis heeft Laura Börjes onderzocht of potentiële boekers/bezoekers van de Living Lodge belangstelling hebben voor Citizen Science en waarom. Van de 105 respondenten gaven er 63 aan belangstelling te hebben voor Citizen Science tijdens een verblijf in de Living Lodge. Zoals verwacht, was de belangstelling het grootst voor het bijdragen aan natuur- en milieu-gerelateerde projecten, en dan vooral via het doen van experimenten, maar ook via het verzamelen van data en het analyseren daarvan. De respondenten toonden minder belangstelling voor het formuleren van onderzoeksvragen.

De belangrijkste motieven om betrokken te willen zijn bij Citizen Science projecten zijn de wens om bij te dragen aan natuurbescherming en maatschappelijke verandering, de wens om iets terug te geven aan de natuur, en de wens om iets te leren over de natuur of over natuurbescher-

ming. De belangrijkste door de respondenten genoemde randvoorwaarden voor het daadwerkelijk bijdragen aan een Citizen Science project zijn dat het makkelijk en leuk moet zijn, dat de resultaten met de deelnemer worden gedeeld, dat het mogelijk is om over het project van gedachten te wisselen met een onderzoeker en dat deelname weinig tijd kost.

Laura Börjes' onderzoek laat verder zien dat gebrek aan continuiteit (door de korte verblijfstijd van gasten) in het geval van de Living Lodge geen probleem hoeft te vor-

men. De Living Lodge als zodanig kan namelijk een langdurige samenwerking aangaan met een onderzoeksproject, zij het met steeds andere 'citizen scientists'.

\section{Bron}

- Börjes, L. (2017). From Tourist to Citizen Scientist? Exploring the Feasibility of Applying Citizen Science at the Living Lodge. BSc Tourism thesis. Wageningen University \& Research, Wageningen.

Dit rapport is op te vragen bij de leerstoelgroep Milieusysteemanalyse (ESA).

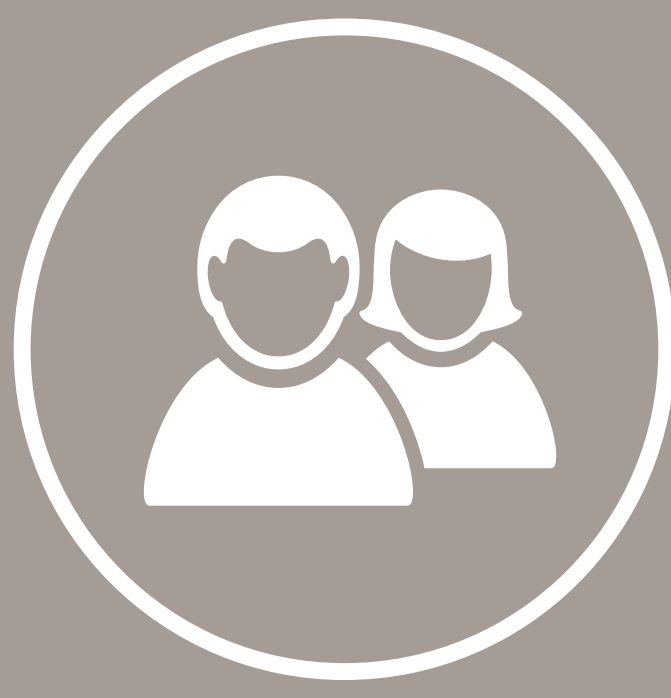




\section{Belangrijkste inzichten}

- Leren in de Living Lodge gaat het best via ervaringen. De verwerking van die ervaringen kan worden gestimuleerd door contact achteraf.

- Voor het verbeteren van de ervaringen van gasten is het belangrijk rekening te houden met de verwachtingen van die gasten.

- Voor wat betreft de Living Lodge lijken de gasten (volgens een vrij beperkte enquête) een bescheiden accommodatie 'midden in de natuur' te verwachten, waar ze kunnen relaxen en fysiek actief kunnen zijn, en waar ze offline informatie tot zich kunnen nemen.

- De inzet van augmented reality technologie kan natuurervaringen versterken en gasten op een speelse manier allerlei dingen leren over de natuur rondom de lodge.

- Apps kunnen ook andere zintuigen prikkelen, zoals de smaak, door gasten te helpen eetbare planten te vinden en daar lekkere gerechten van te maken.

\section{Samenvatting}

Een hoofddoel van het Living Lodge inititatief is gasten intensief in aanraking te laten komen met de natuur rondom de lodge. De natuur ervaren staat centraal, en de bedoeling is dat gasten tijdens dat ervaren ook nog het één en ander opsteken over de natuur. Drie studenten hebben de mogelijkheden verkend om dat leren te versterken. Anne Kruize en Flora Hummel hebben daar hun

\section{Toekomst}

- In vervolgonderzoek kunnen de verwachtingen van de doelgroep uitgebreider in kaart worden gebracht en de mogelijkheden voor verwerking achteraf verder uitgewerkt.

thesis over geschreven, terwijl Julian Lührmann er zijn stage aan heeft gewijd.

Anne Kruize begint vanuit het leren. Zij grijpt terug op leertheorieën van onder andere Kolb, waarin het proces van leren uiteen wordt gerafeld in een aantal fasen, zoals conceptualiseren, ervaren en verwerken. Van nature is de
6 Citizen Science

7 Leren, beleven en ervaren

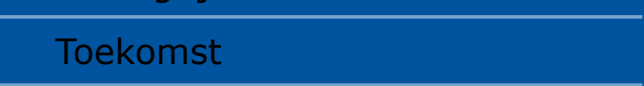

Samenvatting

Bron

8 Voetafdruk

9 Aanbevelingen en een

onderzoeksagenda voor de

nabije toekomst

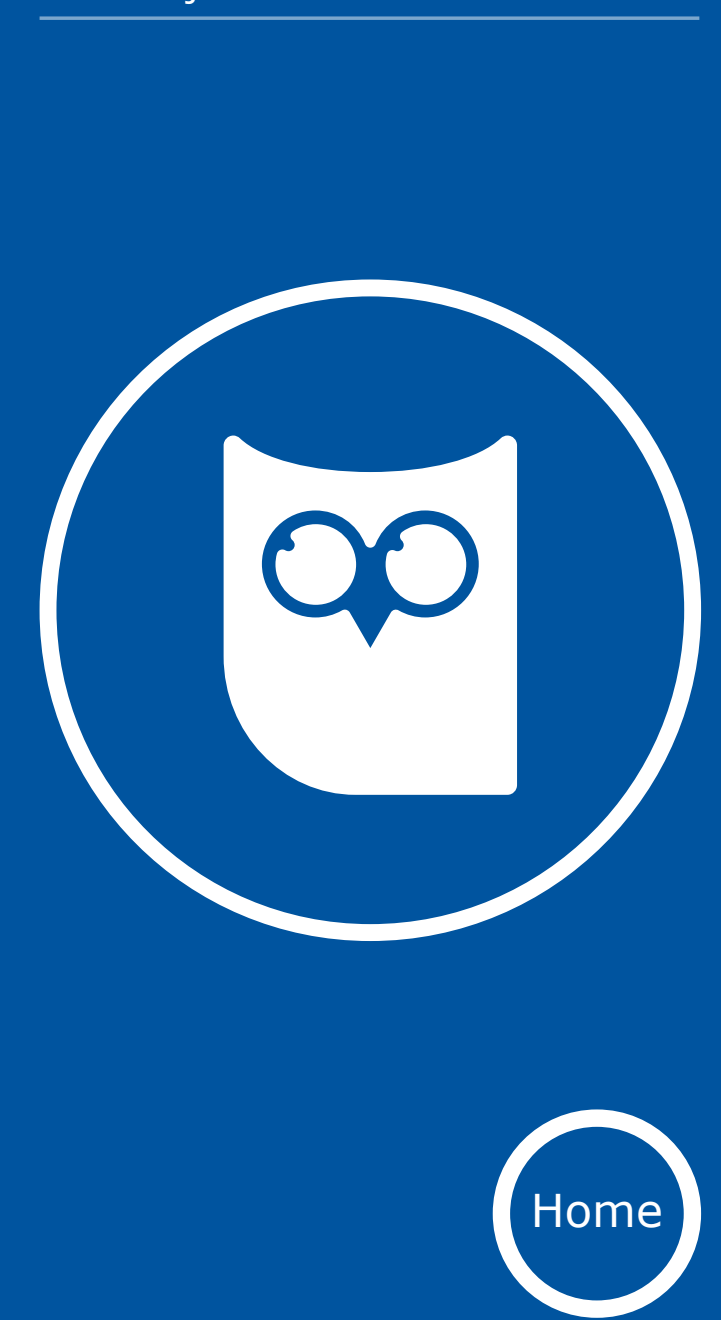


Living Lodge vooral gericht op ervaren, omdat het verblijf in de Living Lodge moet vooral prettig en aangenaam zijn en dus voorkomen moet worden dat het leren als must wordt gezien. Het doornemen van uitgebreide documentatie verhoudt zich bijvoorbeeld slecht met het recreatieve karakter van de Living Lodge. Het leren moet daarom zo ongemerkt mogelijk plaatsvinden. Toch leren mensen pas echt als ze niet alleen ervaren, maar die ervaringen ook verwerken en conceptualiseren. Uit Anne's onderzoek komen twee belangrijke tips naar voren om dat te bereiken: zorg voor ervaringen met een duidelijke educatieve boodschap en stimuleer verwerking van de ervaringen door de gasten na hun verblijf met aanvullende informatie te voeden.

Flora Hummel borduurt in haar thesis verder op het thema 'ervaring'. Zij heeft uitgezocht hoe de Living Lodge ervaringen verder kan versterken. Een eerste belangrijk punt is dat voor een sterke en positieve ervaring het aangeboden product moet aansluiten bij de verwachtingen. De respondenten van Flora's enquête associëren de Living Lodge meer met 'midden in de natuur' dan met luxe. Een teveel aan luxe zou een positieve natuurervaring zelfs in de weg kunnen staan.

Voor wat betreft activiteiten vinden de respondenten vooral 'relaxen' belangrijk, gevolgd door fysieke activiteiten, zoals wandelen, fietsen en kanoën. De respondenten bleken maar weinig belangstelling te hebben voor zogeheten multisensorische activiteiten, waarbij mensen al hun zintuigen gebruiken, terwijl zulke activiteiten in de literatuur juist als heel waardevol worden gezien. Een laatste belangrijke uitkomst is dat een te grote focus op gadgets en andere technische hoogstandjes weleens misplaatst zou kunnen zijn. De meeste respondenten hebben een voorkeur voor papier. Wellicht is deze uitkomst gekoppeld aan het beeld van de Living Lodge als idyllische accommodatie, ver weg van de drukte van de stad en de dagelijkse realiteit van internet en social media.

Julian Lührmann richtte zich tijdens zijn stage bij de Nature Nomads niet op een Living Lodge in Nederland, maar in Afrika. Hij werkte mee aan de ontwikkeling van een lodge-concept voor safari toerisme. Zijn hoofdvraag was: hoe kan nieuwe technologie op een 'coole' manier bijdragen aan een intensere natuur-ervaring? Als antwoord op die vraag ontwikkelde Julian een pakket bestaande uit drie onderdelen: 1) de mogelijkheid voor gasten om te melden welke dieren zij zien; 2) de mogelijkheid om achteraf in het safarikamp allerlei content uitgebreid te bekijken, onder meer om zo technologie-gebruik tijdens de safaritochten zelf te minimaliseren; en 3 ) de inzet van 'augmented reality'. Dit laatste, meest innovatieve onderdeel maakt het onzichtbare zichtbaar. Dat werkt als volgt. Via zogeheten ibeacons wordt de toerist naar interessante plaatsen in het landschap geleid. Daar aangekomen kan zij of hij via augmented reality dingen zien die normaal gesproken verborgen blijven. Zo kan de toerist bijvoorbeeld een kijkje nemen in de termietenheuvel die zij/hij voor zich ziet en meer te weten komen over het leven van een termiet.

Soortgelijke ideeën komen ook terug in het essay van Van Lith en collega's (2017) voor het vak Sustainable Techno-
6 Citizen Science

7 Leren, beleven en ervaren

Belangrijkste inzichten

Toekomst

Samenvatting Bron

8 Voetafdruk

9 Aanbevelingen en een onderzoeksagenda voor de nabije toekomst

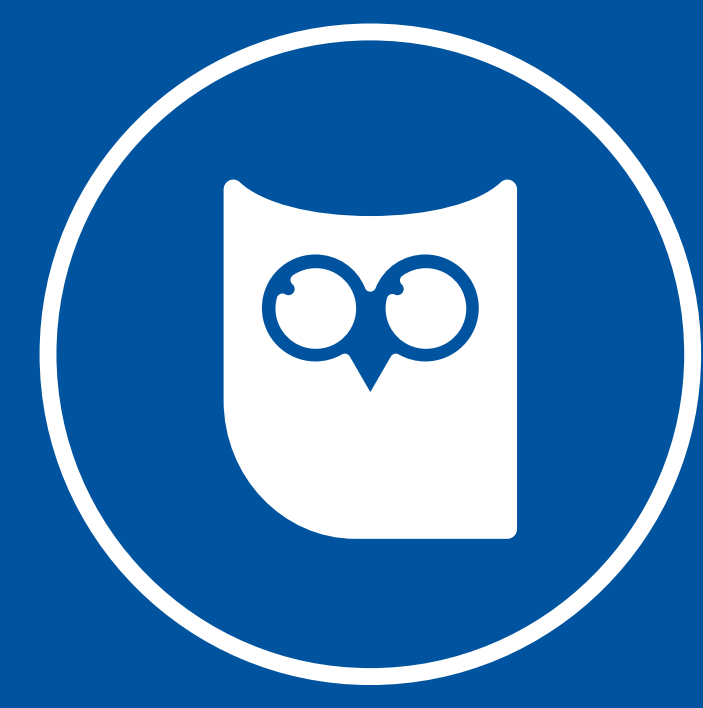


logy Development (STD). De door hen voorgestelde Lodge Escape App stelt gebruikers in staat hun ervaringen te vergemakkelijken, verbreden en verdiepen, door: 1 . het aanbieden van een virtuele kaart met interessante plaatsen rond de lodge om te bezoeken; 2 . het markeren van interessante plaatsen of objecten met QR codes, waarmee gasten toegang krijgen tot aanvullende informatie; 3 . het aanbieden van ervaringen van anderen via video-content; 4. het creëren van een tijdlijn van de ontwikkeling van de Living Lodge; 5 . het toepassen van augmented reality om gasten inzicht te bieden in de werking en achtergrond van objecten in het landschap; en 6 . het aanbieden van een spel gericht op het spotten van zoveel mogelijk plantenen diersoorten

Twee onderdelen van de Lodge Escape App, te weten he duiden van interessante plaatsen en het delen van ervaringen, vormen de kern van de app ontwikkeld door Ariaans en collega's (2017). Het delen van ervaringen komt ook terug in de app van Stolk en collega's (2017) en deze app biedt gasten daarnaast mogelijkheid al voor hun bezoek kennis te maken met de Lodge, bijvoorbeeld via een virtuele rondleiding.

Het STD-essay van Faes en collega's (2017) stelt voor een EcoCircle app te ontwikkelen waarmee Lodge-gasten kunnen ontdekken welke eetbare planten er rond de Lodge staan, wat voor gerechten je daarmee kunt maken en hoe je afval en etensresten kunt composteren.

De laatste twee essays richten zich vooral op het gedrag van de gasten. Börjes en collega's (2017) stellen een app voor die gasten in detail laten zien waar, wanneer en hoeveel water en energie ze gebruiken. De LivingLodgeOS app (Van Baal en collega's, 2017) maakt aan gasten inzichtelijk hoeveel water en energie er in de Lodge verbruikt wordt en hoe het gesteld is met de kwaliteit van de omgeving van de Lodge, in termen van luchtkwaliteit en aanwezige planten- en diersoorten.

\section{Bronnen}

- Diverse essays voor de cursus Sustainable Technology Development, op te vragen bij de leerstoelgroep Milieubeleid (ENP):

- Ariaans, L., Isrif, J., Kleijnen, L., Stock, R., Wapstra, G., en Woning, N. (2017). The Living Lodge Project.

- Börjes, L., Friedrich, N., Homes, W., Hummel, F., en Winter, M. (2017). Sustainability and Technology in Tourism Accommodation: The Living Lodge in the National Park De Biesbosch.

- Faes, S., Van Nimwegen, J., Reijm, S., Thommassen, M., en Vos, A. (2017). The Living Lodge: Ecology and innovations.

- Stolk, N., Jansen, F., Betting, I., Panjer, T., en Evers, B. (2017). The Living Lodge.

- Van Baal, L., Berends, E., Van Iwaarden, M., Peters, S., Tiel Groenestege, M., en Tops, J. (2017). Welcome to Living Lodge.

- Van Lith, A., Nieuwesteeg, P., Verschueren, J. Ghiran, S., De Vette, K. en Tremiliti, E. (2017). The Living Lodge: Accommodating life - Technology as a tool to enhance the tourist lodge experience.
6 Citizen Science

7 Leren, beleven en ervaren

Belangrijkste inzichten

Toekomst

Samenvatting

Bron

8 Voetafdruk

9 Aanbevelingen en een

onderzoeksagenda voor de nabije toekomst

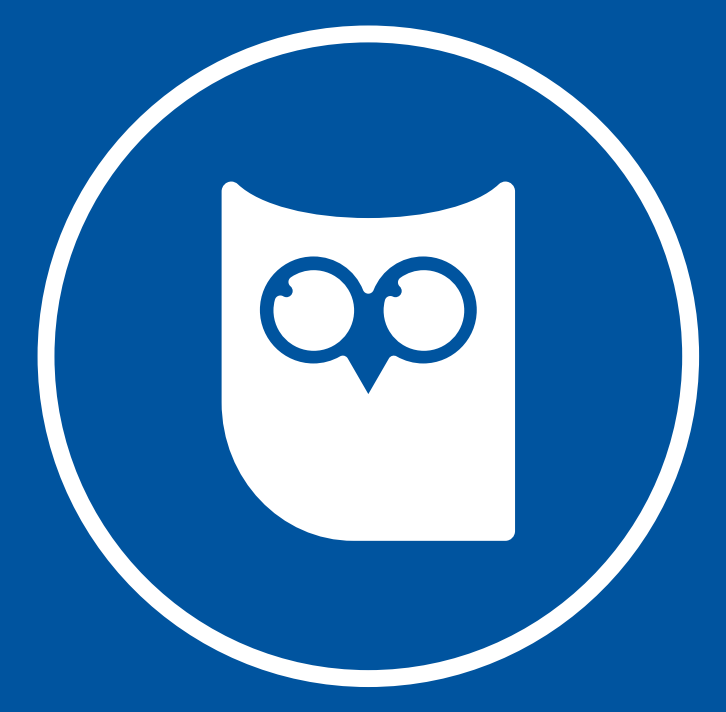


4 Bouwen voor doelsoorten

Monitoren van doelsoorten

- Hummel, F. (2017). Enhancing nature experiences: An evaluation of possibilities for the Living Lodge in the

Dutch national park the Biesbosch. Bsc Tourism thesis.

Wageningen University \& Research, Wageningen.

Dit rapport is op te vragen bij de leerstoelgroep Mili-

eusysteemanalyse (ESA).

- Kruize, A. (2017). The Living Lodge; Connecting tourists and nature through education. Bsc Tourism thesis.

Wageningen University \& Research, Wageningen.

Dit rapport is op te vragen bij de leerstoelgroep Mili-

eusysteemanalyse (ESA).

- Lührmann, F. (2017). Eindrapport stage Living Lodge. Wageningen University \& Research, Wageningen.

Dit rapport is op te vragen bij de leerstoelgroep Culturele Geografie (GEO). 


\section{Belangrijkste inzichten}

- Een volledig autarkische (off-the-grid) Living Lodge is mogelijk, maar het benodigde ruimtebeslag is al snel groter dan de Living Lodge zelf.

- Innovatieve technologieën voor energie- en watervoorziening zijn beschikbaar, maar deze kunnen hoogstwaarschijnlijk slechts een deel van de vraag dekken. Meer gangbare technologieën, zoals zonne-energie en regenwater-opvang en -filtering blijven voorlopig nodig.

\section{Toekomst}

- Zodra er meer bekend is over het ontwerp (o.a. grootte) van de Living Lodge en over de gestelde luxe-eisen (energie- en waterverbruik) kan er een concreter overzicht worden gegeven van de technische mogelijkheden voor autarkie.

Bouwen voor doelsoorten

Monitoren van doelsoorten

6 Citizen Science

7 Leren, beleven en ervaren

8 Voetafdruk

Belangrijkste inzichten

Toekomst

Samenvatting

Bron

9 Aanbevelingen en een onderzoeksagenda voor de nabije toekomst

\section{Samenvatting}

De Living Lodge richt zich vooral op de gast en de levende natuur, maar de energie- en watervoorziening zijn ook van groot belang. Allereerst is er een praktisch belang: de lodges zullen worden geplaatst in afgelegen natuurgebieden, waar aansluiting aan de reguliere energie- en waternetwerken niet haalbaar en ook niet wenselijk is. Daarnaast zou een grote ecologische voetafdruk van de lodge op gespannen voet staan met de verdere ecologische uitstraling.

Een groep studenten heeft in het kader van het vak Environmental Project Studies (EPS) onderzoek gedaan naar de mogelijkheden voor innovatieve manieren van energieen watervoorziening die zouden kunnen passen bij de Living Lodge (De Jong en collega's, 2016). In hun rapport geeft de groep een vrij uitgebreid overzicht van beschikbare methoden en technologieën. Voor energie onder-

scheiden ze daarbij drie clusters: i) energie opwekking, ii) energie opslag en iii) verwarming en koeling. Voor water onderscheidt de groep eveneens drie clusters: i) watervoorziening en -opslag; ii) afvalwaterverwerking en iii) filters. Ook bekijken ze een aantal concrete voorbeelden van pogingen om gebouwen zo zelf-voorzienend mogelijk te maken in termen van energie en water. Tenslotte bespreekt de groep een drietal mogelijke configuraties van water- en energietechnologieën voor de Living Lodge, elk geoptimaliseerd voor een ander doel, respectievelijk de mate van zelfvoorzienendheid, ruimtebeslag en innovatief karakter.

Via het opvangen van regenwater, gecombineerd met nano-, ultra- en UV-filters, kan in alle scenario's aan de watervraag worden voldaan. Wel is er sprake van mogelijke concurrentie met zonne-energie voor wat betreft het

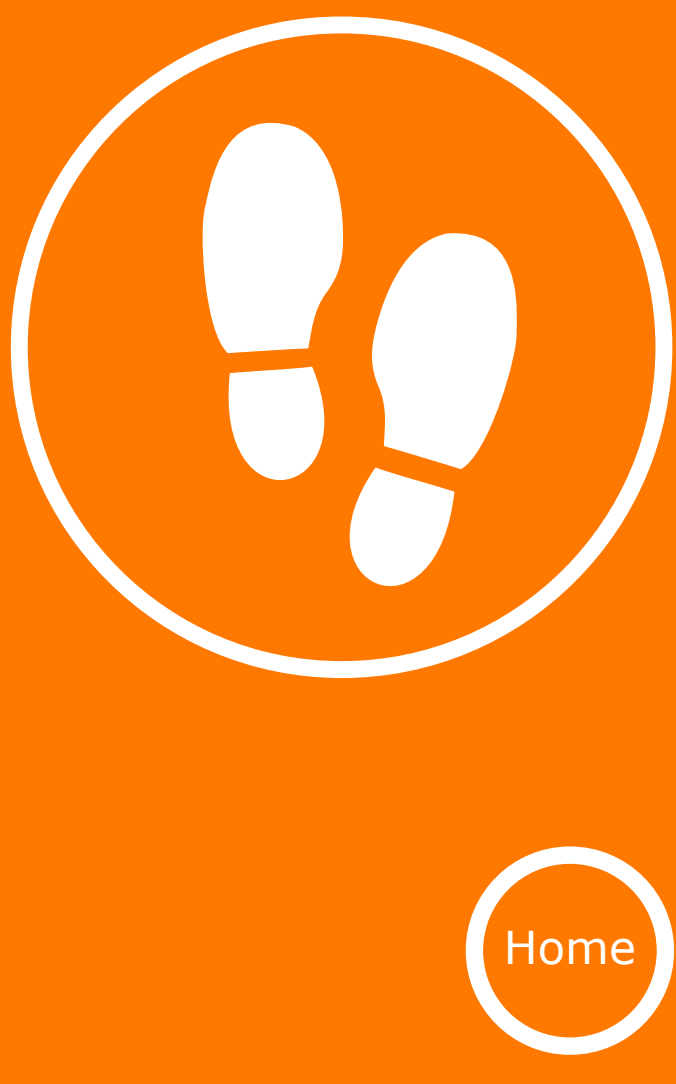


beschikbare (dak-)oppervlak. Een meer innovatieve invulling van de energiebehoefte kan liggen in de inzet van windturbines. De mogelijkheden voor het inzetten van getijde-energie bleken beperkt. Voor de opslag van energie zijn in alle gevallen batterijen nodig. Ook een combinatie met verwarmen en koelen via warmte-opslag behoort tot de mogelijkheden.

Het tweede bouwkundig rapport (Nijkamp en collega's, 2017) biedt vergelijkbare inzichten in de mogelijke technische oplossingen, maar wijst ook op een aantal nieuwe beperkingen. Volgens dit rapport is gebruik van gefilterd hemelwater en afvalwater, bijvoorbeeld om de was te doen of de WC door te spoelen, volgens de wet wel toegestaan voor eigen gebruik, maar niet voor gebruik door derden. Dat is een knelpunt voor de Living Lodge. Drinkwater zal hoe dan ook van elders moeten worden aangevoerd. Nijkamp en collega's zien verder mogelijkheden voor het gebruik van zonnepanelen die naast energie ook warmte leveren. Net als het EPS-rapport wijst dit rapport op een mogelijk gebrek aan bruikbaar oppervlakte, ook vanwege schaduwwerking. Verder wijst het op de noodzaak om naast zonnepanelen ook andere energiebronnen zoals wind en biomassa te gebruiken om tekorten in de winter en op donkere dagen te voorkomen.

\section{Bron}

- De Jong, H.W., Meppelink, M., Schumacher, L.H., Stokkermans, L., De Vette, K.O., Weingarten, I. en Zandbergen, J.A.H. (2016). The Living Lodge: Research on achieving sustainable self-sufficiency of a tourist accommodation in the Biesbosch. Final groupwork report for ETE-25812. Wageningen University \& Research, Wageningen.

Dit rapport is te downloaden vanaf de website van de wetenschapswinkel

- Nijkamp, N., Kleine Schaars, D., Hein, A., Steeghs, T., en Limpens, P. (2017). Eindverslag bouwkundewinkel project Living Lodge. University of Technology Eindhoven, Eindhoven.

Dit rapport is op te vragen bij de bouwkundewinkel.
1. Voorwoord \& inleiding

Opzet van het project

Selecteren van doelsoorten

Bouwen voor doelsoorten

Monitoren van doelsoorten

6 Citizen Science

7 Leren, beleven en ervaren

8 Voetafdruk

Belangrijkste inzichten

Toekomst

Samenvatting

Bron

9 Aanbevelingen en een onderzoeksagenda voor de nabije toekomst

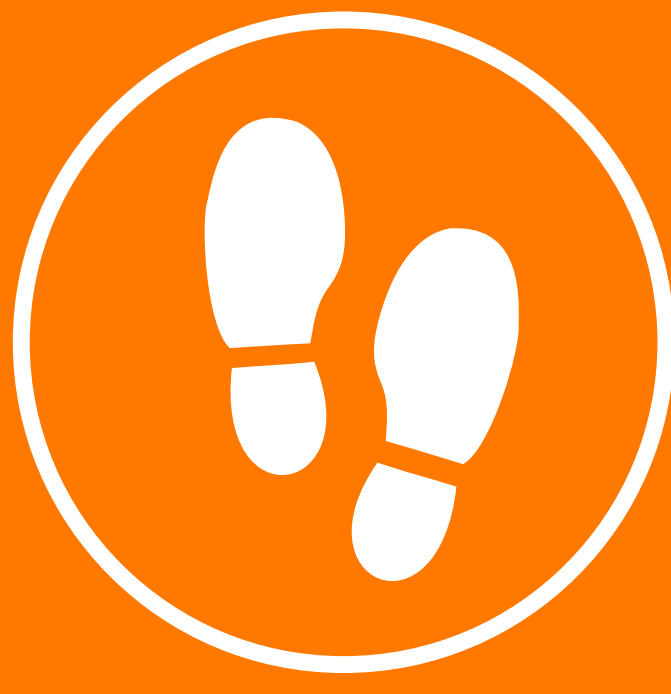


De Living Lodge is een prikkelend en inspirerend idee. Een manier van bouwen die de natuur ten goede komt én ervoor zorgt dat mensen de natuur op een inspirerende en intense manier beleven. De positieve insteek en de oplossingsgerichtheid van het Living Lodge idee zorgen voor inspiratie en dagen mensen uit om na te gaan hoe ze zelf een bijdrage kunnen leveren. Ook in Wageningen. Na een bescheiden start heeft het Wetenschapswinkelproject zich als een spreekwoordelijke olievlek uitgebreid. In de afgelopen jaren hebben tientallen studenten en medewerkers met veel inzet gewerkt aan de verdere ontwikkeling van de Living Lodge. Dat heeft gezorgd voor een groeiende aanhang van het Living Lodge ideaal. Maar ook inhoudelijk zijn er stappen gezet.

Zo is er nu op het ecologische vlak nu een duidelijk omschreven methode om doelsoorten te selecteren en om de ontwikkeling van die doelsoorten te monitoren. Op het bouwkundige vlak is er een inventarisatie gemaakt van 'groen-elementen' die de ruimte op en om de Living Lodge aantrekkelijk kunnen maken als habitat voor de doelsoorten. Ook zijn de eerste concrete ontwerpen van de Living Lodge gemaakt. Verder is duidelijker geworden hoe de Living Lodge off-the-grid kan opereren. Tenslotte is er het nodige theoretische en empirische werk verzet rondom de verwachtingen en beleving van de toekomstige menselijke gasten van de Living Lodge. Die gasten blijken niet op zoek naar luxe en technologische hoogstandjes, maar naar een bescheiden accommodatie midden in de natuur, waar ze hun ervaringen kunnen opdoen. Ook blijken zij graag bij te willen dragen aan onderzoek aan de natuur rondom de Living Lodge. Dat biedt mogelijkheden voor een verdere versterking en verdieping van de natuur-ervaring van de gasten én voor een effectieve monitoring van de effecten van de Living Lodge op de natuur eromheen.

Al met al zijn de contouren van een Living Lodge een stuk duidelijker geworden. De Living Lodge lijkt al bijna tastbaar, toch moet de eerste nog gebouwd worden. Voor de verdere ontwikkeling van het concept is het daadwerkelijk bouwen van een lodge essentieel. De stap naar bouwen zal bestaande onderzoeksvragen verder concretiseren en daarnaast ongetwijfeld nieuwe onderzoeksvragen opleveren. Het lijkt erop dat de eerste Living Lodge niet lang meer op zich zal laten wachten: binnen een jaar of twee staat er als het goed is een Living Lodge in de Biesbosch. En misschien verrijst er ook wel een Living Lab op de WUR campus. De mogelijkheden daarvoor worden momenteel verkend. Een Living Lab is een gebouw met dezelfde ecologische uitgangspunten als de Living Lodge, maar met de nadruk op onderzoek en onderwijs. Het Living Lab moet een gebouw worden gebouw waarmee en waarin studenten naar hartenlust kunnen experimenteren met verbeteringen aan de Living Lodge concepten. Dat zou een prachtig vervolg zijn op dit Wetenschapswinkel project
4 Bouwen voor doelsoorten

Monitoren van doelsoorten

Citizen Science

Leren, beleven en ervaren

8 Voetafdruk

Aanbevelingen en een onderzoeksagenda voor de nabije toekomst

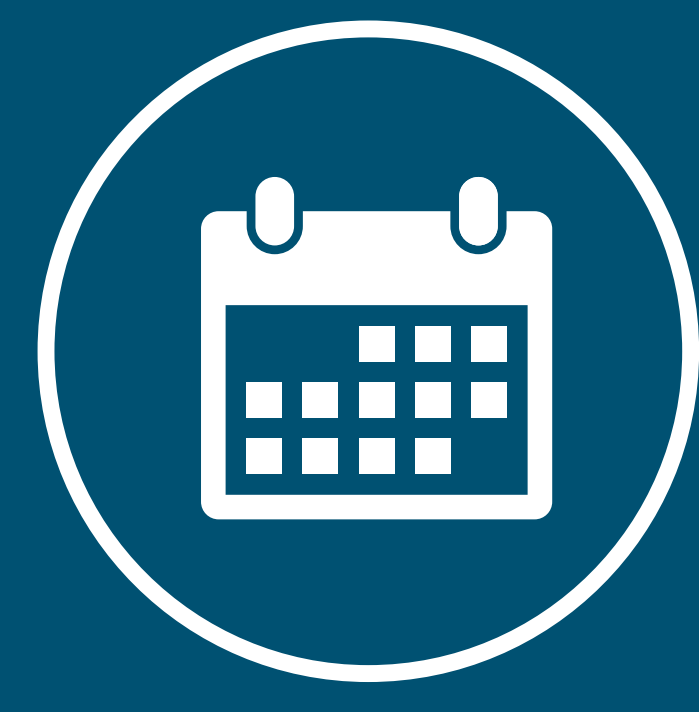


